\title{
Effects of Vitamin E and Selenium on Fertility and Lamb Performance of Yankasa Sheep
}

\author{
Suleman Ibrahim Musa1, Immanuel Iordoo Bitto², John Adisa Ayoade ${ }^{3}$, \\ Olugbenga Emmanuel Oyedipe ${ }^{4}$
}

\author{
${ }^{1}$ Department of Animal Science, Nasarawa State University, Keffi, Nigeria \\ ${ }^{2}$ Department of Animal Breading and Physiology, University of Agriculture in Makurdi, Makurdi, Nigeria \\ ${ }^{3}$ Department of Animal Production, University of Agriculture in Makurdi, Makurdi, Nigeria \\ ${ }^{4}$ College of Veterinary Medicine, University of Agriculture in Makurdi, Makurdi, Nigeria \\ Email: dribmazara@yahoo.com
}

How to cite this paper: Musa, S.I., Bitto, I.I., Ayoade, J.A. and Oyedipe, O.E. (2018) Effects of Vitamin E and Selenium on Fertility and Lamb Performance of Yankasa Sheep. Open Journal of Veterinary Medicine, 8, 167-173.

https://doi.org/10.4236/ojvm.2018.89015

Received: December 23, 2017

Accepted: September 14, 2018

Published: September 17, 2018

Copyright (C) 2018 by authors and Scientific Research Publishing Inc. This work is licensed under the Creative Commons Attribution International License (CC BY 4.0)

http://creativecommons.org/licenses/by/4.0/

\section{Open Access}

\begin{abstract}
Effects of vitamin E and Selenium administration on fertility and lamb performance of Yankasa sheep were evaluated. Thirty post pubertal ewes (1-1 1/2 years of age) and nine rams (2-2 1/2 years of age) were used for the study. The ewes were randomly assigned into 3 groups $(n=10)$. Animals in group 1 served as control and were administered $1 \mathrm{ml}$ normal saline. Animals in group 2 were administered $90 \mathrm{mg}$ Tocopherol acetate (Vitamin E), while group 3 received injection containing a combination of $100 \mathrm{mg}$ tocopherol acetate and $1.97 \mathrm{mg}$ sodium selenite. Two doses of the injections were administered 14 days apart (subcutaneously). Estrus was synchronized in the ewes using controlled internal drug release device (CIDR). Rams were used for estrus detection and mating starting 24 hours following withdrawal of CIDR. Ewes were allowed to carry the pregnancy to term. The results indicate higher $(\mathrm{p}<0.05)$ estrus response $(80.00,100.00,100.00)$, pregnancy rate $(75.00,100.00,100.00)$ and lambing rate $(66.6,100.00,100.00)$ in ewes following administration of vitamin $\mathrm{E}$ and a combination of vitamin $\mathrm{E}$ and selenium. Average daily weight gain of lambs was also significantly enhanced $(\mathrm{p}<0.05)$ by treatment. It can be concluded that administration of Vitamin $\mathrm{E}$ alone and in combination with selenium resulted in improved reproductive performance on Yankasa sheep.
\end{abstract}

\section{Keywords}

Vitamin E, Selenium, Reproductive Performance, Yankasa Sheep

\section{Introduction}

Sheep production plays a significant role in the food chain and livelihood of ru- 
ral households [1]. The Yankasa sheep is the most numerous breed of sheep in Nigeria and also has the widest distribution. Reproductive performance is reported to be an important determining factor for profitability in sheep breeding [2]. The adverse effect of nutritional stress on follicular development, embryo quality and embryo-mother signaling has been documented [3]. Vitamin E acts as an intra cellular antioxidant thereby protecting cellular membranes from oxidative damage [4]. Selenium is an essential component of glutathione peroxidase an enzyme involved in detoxification of free radicals [5]. Selenium supplementation has been reported to improve reproductive performance of sheep. The adverse effects of oxidative stress on ovarian function have also been documented. Soil selenium concentration in the study area has been reported to be below the critical level of $0.05 \mathrm{mg} / \mathrm{kg}$ [6]. Selenium deficiency has also been reported in legumes and crop residue in the study area [7]. The objective of this study is to evaluate the effects of selenium and vitamin E supplementation on fertility and lamb performance in Yankasa sheep.

\section{Materials and Methods}

\subsection{Experiment Site}

This study was conducted in the livestock farm of the Department of Animal Science of College Agriculture, Lafia, Nasarawa state, Nigeria. The location lies within latitude $08^{\circ} 33^{\prime} \mathrm{N}$ and longitude $08^{\circ} 33^{\prime} \mathrm{E}$ at an attitude of $181.53 \mathrm{~m}(570 \mathrm{ft})$ above sea level with an annual rainfall of $1311.75 \mathrm{~cm}$

\subsection{Animals and Management}

Thirty post pubertal Yankasa ewes (1-1 $1 / 2$ yrs of age) weighing $22.5-26.1 \mathrm{~kg}$ and nine (9) Rams (2-2 1/2 years of age) weighing $36-42 \mathrm{~kg}$ were used for the study. The animals were allowed access to grazing most of the day. Maize offal was provided as supplementary feed and Minerals salt lick and clean drinking water provided ad libitum. All animals were given prophylactic treatment against ecto and endo parasites, by using ivermectin ( $50 \mu \mathrm{g} / \mathrm{kg}$ subcutaneously).

\subsection{Experimental Procedure}

The animals were kept for a stabilization period of 14 days before commencement of the experiment. Pregnancy evaluation was done by determination of serum progesterone levels. Ewes with serum progesterone concentration below $1.2 \mathrm{ng} / \mathrm{ml}$ were considered non pregnant [8]. The Ewes were divided into 3 groups with 10 ewes per group. Animals in group 1 serve as control and were administered $1 \mathrm{ml}$ normal saline, animals in group 2 were administered injections of $90 \mathrm{mg}$ Tocopherol Acetate (Vitamin E), manufactured be Laborate Pharmaceutical (India). Ewes in group 3 received injections containing $100 \mathrm{mg}$ Tocopherol Acetate (Vitamin E) and 1.97 mg Sodium Selenite (Bremer Pharma GMBH) Germany. All injections were administered subcutaneously. Two doses of the injections were administered 14 days apart. 


\subsection{Estrus Synchronization and Mating}

Estrus was synchronized in all ewes using controlled internal Drug release (CIDR) device impregnated with $300 \mathrm{mg}$ progesterone. The device was inserted $3 \mathrm{~cm}$ into the Vagina using an applicator and left in place for 14 days according to manufacturer's instructions. The Rams were used for estrus detection and natural mating starting 24 hours after withdrawal of CIDR. Estrus detection was done twice daily, ewes showing signs of estrus were allowed to run with the Rams until they were out of estrus. Ewes exhibiting estrus within 5 days (120 hours) following treatment were considered synchronized. Pregnant ewes were allowed to carry the pregnancy to term.

\subsection{Data Collection}

The following parameters were recorded.

$$
\text { Percentage of Animals in Estrus }=\frac{\text { Number of ewes in estrus } \times 100}{\text { Number of ewes in group }}
$$

Duration of estrus (Hours)

Interval to estrus (Hours)

$$
\text { Pregnancy Rate }=\frac{\text { Number of pregnant ewes } \times 100}{\text { Number mated in group }}
$$

incidence of retained placenta, Dystocia and Stillbirth.

$$
\begin{gathered}
\text { Lambing Rate }=\frac{\text { Number of ewes lambing }}{\text { Number of mated ewes in group }} \times 100 \\
\text { Fecundity }=\frac{\text { Number of lambs born }}{\text { Number of lambing ewes }}
\end{gathered}
$$

Lamb performance Parameters evaluated include birth weight, Weight at 30 days of age, and average daily weight gain.

\subsection{Statistical Analysis}

The data were analyzed by analysis of variance using statistical package for social science (SPSS) version 22.0. The separation of means was effected using Duncan's Multiple Range Test (DMRT) method while statement of significance was based on $\mathrm{p}<0.05$.

\section{Results}

\subsection{Estrus Response and Fertility}

Data on Estrus response and fertility are presented in Table 1. Percentage estrus response is significantly higher $(\mathrm{p}<0.05)$ in groups 2 and 3 compared to the control. Mean values for response interval and duration of estrus were similar for all groups ( $p>0.05)$. Pregnancy rates (\%) for groups 2 and 3 are similar but significantly high compared to the control group $(\mathrm{p}<0.05)$. 
Mean values of lambing rates $(\%)$ differed significantly $(\mathrm{p}<0.05)$ between treatments with the control group being significantly lower compared to other groups which were similar. Treatment had no significant effect on fecundity rate $(\%)$.

\subsection{Birth Weight and Growth Performance of Lambs}

Summary of the effects of treatment on birth weight and growth performance of lambs are presented on Table 2. Mean values of birth weight are similar for all groups ( $\mathrm{p}>0.05$ ) weight at 30 days of age and average daily gain are significantly lower $(\mathrm{p}<0.05)$ in the control compared to other groups which were similar.

\subsection{Parturition Parameters}

Summary of effects of treatment on some parturition parameters are presented in Table 3. Mean values of incidence of Dystocia are similar for all groups ( $p>$ 0.05). Incidence of Still birth and number of cases of Retained fetal membrane are significantly higher $(\mathrm{p}<0.05)$ in the control group compared to groups 2 and 3 which were similar.

Table 1. Effects of selenium and vitamin E on estrus and fertility of Yankasa ewes (mean \pm sem).

\begin{tabular}{|c|c|c|c|c|}
\hline \multirow{2}{*}{ Parameters } & \multirow{2}{*}{ Control } & \multicolumn{2}{|c|}{ Treatments } & \\
\hline & & Vitamin E & Se \pm Vit. E & \\
\hline Estrous response & $80.00 \pm 0.00^{\mathrm{a}}$ & $100.0 \pm 0.00^{\mathrm{b}}$ & $100.0 \pm 0.00^{\mathrm{b}}$ & * \\
\hline Response interval (Hours) & $30.75 \pm 3.03$ & $30.50 \pm 3.20$ & $30.50 \pm 2.88$ & ns \\
\hline Duration of estrus (Hours) & $31.25 \pm 2.75$ & $31.75 \pm 2.42$ & $31.00 \pm 2.88$ & ns \\
\hline Pregnancy rate $(\%)$ & $75.00 \pm 0.00^{\mathrm{a}}$ & $80.00 \pm 0.00^{\mathrm{b}}$ & $80.00 \pm 0.00^{\mathrm{b}}$ & * \\
\hline Lambing rate $(\%)$ & $66.60 \pm 0.00^{\mathrm{a}}$ & $100.00 \pm 0.00^{\mathrm{b}}$ & $100.00 \pm 0.00^{\mathrm{b}}$ & * \\
\hline Fecundity rate (\%) & $100.00 \pm 0.00$ & $100.00 \pm 0.00$ & $100.00 \pm 0.00$ & Ns \\
\hline
\end{tabular}

Means within same row bearing different superscript are significantly different $(\mathrm{p}<0.05)$. SEM-standard error or mean, $\mathrm{ns}=$ Not significant. ${ }^{*}$-Significant $(\mathrm{p}<0.05)$.

Table 2. Effects of selenium and vitamin E on birth weight and growth performance of lambs (mean \pm sem).

\begin{tabular}{ccccc}
\hline \multirow{2}{*}{ Parameters } & Control & \multicolumn{2}{c}{ Treatment } & \\
\cline { 3 - 4 } & & Vitamin E & Se \pm Vit. E & \\
\hline Birth weight $(\mathrm{kg})$ & $2.30 \pm 0.00$ & $2.35 \pm 0.06$ & $2.32 \pm 0.08$ & ns \\
Weight at 30 days of age (kg) & $4.65 \pm 0.02^{\mathrm{a}}$ & $5.07 \pm 0.04^{\mathrm{b}}$ & $5.07 \pm 0.47^{\mathrm{b}}$ & \\
Average daily weight gain $(\mathrm{g})$ & $80.00 \pm 0.00^{\mathrm{a}}$ & $90.50 \pm 3.78^{\mathrm{b}}$ & $91.25 \pm 4.44^{\mathrm{b}}$ & $*$ \\
\hline
\end{tabular}

Means within same row bearing different superscript are significantly different $(\mathrm{p}<0.05)$. SEM-standard error or mean, $\mathrm{ns}=$ Not significant. ${ }^{*}$-Significant $(\mathrm{p}<0.05)$. 
Table 3. Effects of selenium and vitamin E on some parturition parameters of Yankasa ewes (mean \pm sem).

\begin{tabular}{ccccc}
\hline \multirow{2}{*}{ Parameters } & Control & \multicolumn{2}{c}{ Treatment } & \\
\cline { 3 - 4 } & & Vitamin E & Se \pm Vit. E & \\
\hline Incidence of dystocia & $0.00 \pm 0.00$ & $0.00 \pm 0.00$ & $0.00 \pm 0.00$ & $\mathrm{~ns}$ \\
Incidence of still birth & $1.00 \pm 0.00$ & $0.00 \pm 0.00^{\mathrm{a}}$ & $0.00 \pm 0.00^{\mathrm{a}}$ & $*$ \\
Number of cases of retained placenta & $1.00 \pm 0.00$ & $0.00 \pm 0.00^{\mathrm{a}}$ & $0.000 .00^{\mathrm{a}}$ & $*$ \\
\hline
\end{tabular}

Means within same row bearing different superscript are significantly different. SEM-standard error or mean, ns $=$ Not significant, ${ }^{*}$-Significant $(\mathrm{p}<0.05)$.

\section{Discussion}

Higher oestrous response, pregnancy rate and lambing rate were induced following administration of Vitamin $\mathrm{E}$ and a combination of Vitamin $\mathrm{E}$ and selenium $(\mathrm{p}<0.05)$. Mean values of interval to estrus, duration of estrus and fecundity rate were however, similar between all groups. These findings are similar to reports of [9] who reported significant improvement in estrus response and fertility following administration of Vitamin E and Selenium in Merino ewes. Similarly, [10] [11] reported beneficial effect on ewe fertility following supplementation with Vitamin $\mathrm{E}$ and Selenium. These effects are attributed to the function of Vitamin $\mathrm{E}$ as an intra cellular antioxidant, scavenging reactive oxygen species thereby protecting cellular membranes from oxidative damage. Selenium acts as a co-factor in glutathione peroxidase enzyme system responsible for extra cellular detoxification of free radicals [5].

Reactive oxygen species are involved in folliculogenesis, oocyte maturation, ovulation, formation and regression of corpus luteum, implantation and fetal development. Oxidative stress has been associated with fertilization failure, implantation failure, embryonic death and abortion [12]. The adverse effect of free radicals on ovarian follicles has been reported, thereby suggesting that oxidative stress underlines the mechanism of ovarian aging [13]. The age related decline in fertility has been attributed to the adverse effect of reactive oxygen species [14].

Body weight of lamb at 30 days of age was significantly improved by administration of vitamin E and a combination of vitamin E and Selenium. Similarly, average weight gain $(80.00,90.50$ and 91.25$)$ was enhanced $(p<0.05)$ following administration of Vitamin E and Selenium. The beneficial effect of Selenium and vitamin supplementation on lamb body weight and daily weight gain has earlier been reported [8]. Average daily gain of $79.3 \mathrm{~g}$ had been reported by [15], whereas, [1] observed daily weight gain of $91.8 \mathrm{~g}$.

The result indicates beneficial effects of Vitamin $\mathrm{E}$ and a combination of vitamin $\mathrm{E}$ and selenium on incidence of still birth and retained fetal membranes ( $\mathrm{p}$ $<0.05)$. However, the incidence of dystocia is similar for all groups $(\mathrm{p}>0.05)$. Selenium deficiency had been associated with retained fetal membrane and neonatal mortality [16]. Further information on the use of selenium and vitamin E to improve the reproductive efficiency of sheep may be obtained by applica- 
tion of varying doses of selenium and vitamin $\mathrm{E}$.

\section{Conclusion}

The result of this study indicates improved reproductive performance of Yankasa sheep following administration of vitamin $\mathrm{E}$ and selenium. Lamb performance and average weight gain were also enhanced by treatments.

\section{Ethical Consideration}

Guidelines on animal welfare were strictly followed in the conduct of this research.

\section{Conflicts of Interest}

This research did not receive any specific grant from funding agencies in the public, commercial or not for profit sector.

\section{References}

[1] Osinowo, O.A., Abubakar, B.Y., Olayemi, M.E., Balogun, R.D., Onifade, O.S., Adewuyi, A.A., Trimnell, A.R. and Dennar, F.O. (1991) Pre Weaning Performance of Yankasa Sheep under Semi-Intensive Management. Proceedings of the Second Biennial Conference of African Small Ruminant Research Network, Arusha, Tanzania, 7-11 December 1991, 107-111.

[2] Karakus, K., Nihat, M., Haudan, M., Ibranim, Y., Turguk, A. and Mohammad, M.T. (2016) Relationship between Vitamin Composition and Spermatological Characteristics in Semen of Different Ram Breeds of Turkey. Pakistan Journal of Zoology, 48, 969-975.

[3] Abecia, J.A., Sosa, C., Forfaca, F. and Meikle, A. (2006) The Effect of under Nutrition on the Establishment of Pregnancy in the Ewe. Reproduction Nutrition and Development, 46, 367-378. https://doi.org/10.1051/rnd:2006018

[4] Surai, P. (1999) Vitamin E in Avian Reproduction. Poultry and Avian Biology Review, 10, 1-60.

[5] Smith, O.B. and Akinbamijo, O.O. (2000) Micronutrients and Reproduction in Farm Animals. Animal Reproduction Science, 60-61, 549-560.

https://doi.org/10.1016/S0378-4320(00)00114-7

[6] Ahola, D.O., Rufus, S., Ishaq, S.E. and Michael, H.I. (2017) Levels of Selenium in Vegetables, Medicinal Plants and Soil from Selected Sites within the Lower Benue River Basin Catchment Area. Nigerian Journal of Environmental Science, Toxicology and Food Technology, 2, 21-30.

[7] Ogebe, P.O., Ayoade, J.A., McDowell, L.R., Wilkkerson, N.S. and Martin, F.G. (1995) Mineral Concentrations of Forages and Soils in Benue State, Nigeria. Communication in Soil Science and Plant Analysis, 26, 13-14.

[8] Boscos, C.M., Samartz, F.C., Lymbero, A.G., Stefanakis, A. and Belibasaki, S. (2003) Assessment of Progesterone Concentration Using Enzyme Immuno Assay for Early Pregnancy Diagnosis in Sheep and Goats. Reproduction in Domestic Animals, 38, 170-174. https://doi.org/10.1046/j.1439-0531.2003.00407.x

[9] Koyuncu, M. and Yerlikaya, H. (2007) Effect of Selenium-Vitamin E Injections of Ewes on Reproduction and Growth of Their Lambs. South African Journal of Ani- 
mal Science, 37, 233-236.

[10] Gabryszuk, M. and Klewiec, J. (2002) Effect of Injecting 2- and 3-Year-Old Ewes with Selenium and Selenium-Vitamin E on Reproduction and Rearing of Lambs. Small Ruminant Research, 43, 127-132. https://doi.org/10.1016/S0921-4488(02)00005-6

[11] Segerson, E.C. and Ganopathy, S.N. (2008) Fertilization of Ova in Selenium/Vitamin E Treated Ewes Maintained on Two Plane of Nutrition. Journal of Animal Science, 51, 386-394. https://doi.org/10.2527/jas1980.512386x

[12] Cetin, I., Berti, C. and Calabrese, S. (2010) Role of Micronutrients in the Periconceptional Period. Human Reproduction Update, 16, 80-95. https://doi.org/10.1093/humupd/dmp025

[13] Miyamoto, K., Sato, E.F., Kasahara, E., Jikumaru, M., Hiramoto, K., Tabata, H., Katsuragi, M., Odo, S., Utsumi, K. and Inoue, M (2010) Effect of Oxidative Stress during Repeated Ovulation on the Structure and Functions of the Ovary, Oocytes, and Their Mitochondria. Free Radical Biology and Medicine, 49, 674-681. https://doi.org/10.1016/j.freeradbiomed.2010.05.025

[14] Agarwal, A., Gupta, S. and Sharma, R.K. (2005) Role of Oxidative Stress in Female Reproduction. Reproductive Biology and Endocrinology, 3, 28. https://doi.org/10.1186/1477-7827-3-28

[15] Akpa, G.N., Osinowo, O.A., Dim, N.I. and Oyedipe, E.O. (1994) Effects of Plane of Nutrition and Rearing Method on Yankasa Lambs; Growth Rate, Scrotal Development and Productivity. Nigerian Journal of Animal Production, 21, 101-104.

[16] Moeini, M.M. and Jalilian, M.T. (2014) Effect of Selenium and Vitamin E Injection during Late Pregnancy on Immune System and Productive Performances of Sanjabi Ewes and Their Lambs. Global Journal of Animal Scientific Research, 2, 210-219. 